(C) 1983. The Genetical Society of Great Britain

\title{
DNA VARIATION IN FESTUCA
}

\author{
A. G. SEAL \\ Department of Agricultural Botany, University College of Wales, Aberystwyth, U.K.* \\ Received 9.xii.82
}

\begin{abstract}
SUMMARY
There is substantial interspecific variation in nuclear DNA content in Festuca much of which cannot be accounted for by variation in chromosome number. The distribution of species DNA contents closely matches the taxonomic divisions within the genus. Polyploid taxa, especially high polyploids, tend to have less DNA than expected.

(a) There may be errors in the proposed modes of origin of polyploid forms. In particular, the distinction between European and Moroccan forms may have been underestimated, and/or

(b) polyploid species may have undergone a reduction in nuclear DNA content since their divergence, relative to their progenitor species of lower ploidy.
\end{abstract}

\section{INTRODUCTION}

The genus Festuca (Poaceae) comprises about 100 species of wide geographical distribution, some of which are important herbage crops in temperate regions (Malik and Thomas, 1966). Information contributing to an understanding of species relationships within the genus would be of use to breeders wishing to incorporate the desirable characteristics of many wild species into the agronomically important varieties (Chandrasekharan and Thomas, 1971a).

Cytologically the genus is diverse. Chromosome number ranges from diploid $(2 n=14)$ to decaploid $(2 n=70)$. About 74 per cent of species occur as polyploids (Malik and Thomas, 1966). Supernumerary chromosomes have been found in several species (Jones, 1975). Chromosome morphology varies between species and populations (Malik and Thomas, 1966). Heteromorphic bivalents are often found at meiosis in interspecific hybrids (Malik and Thomas, 1967). This suggests that, during or following speciation, homoeologous chromosomes have diverged in size and, therefore, in nuclear DNA content. Extensive interspecific variation in nuclear DNA content exists in the closely related genus, Lolium (Rees and Jones, 1967).

In this work, a survey of the genus Festuca was made in order to assess the extent and pattern of variation in nuclear DNA content among a wide range of taxa, both diploid and polyploid. The degree to which the observed variation coincided with taxonomic divisions based on other criteria was examined and the possibility of using DNA contents in tracing the ancestry of polyploids was considered.

* Present address: Plant Breeding Institute, Maris Lane, Trumpington, Cambridge CB2 2LQ, U.K. 


\section{Materials AND METHOdS}

The taxa used and their seed sources are shown in table 1. The DNA contents of Feulgen stained nuclei were estimated by microdensitometry (estimates of nuclear area were obtained simultaneously). The method is described in detail by Seal and Rees (1982). The 2C nuclear DNA content of $F$. pratensis cv. S215 was estimated to be $3.96 \mathrm{pg}$ by comparison with Allium cepa (33.5 pg, Van't Hof, 1965) and was used as a standard with which all other estimates were compared.

TABLE 1

Sources of plant material

\begin{tabular}{|c|c|c|}
\hline & Taxon & Source \\
\hline 1. & F. polesica Zapal. & W.P.B.S.* \\
\hline 2. & F. scariosa & W.P.B.S. \\
\hline 3. & F. altissima All. & W.P.B.S. \\
\hline 4. & F. donax & W.P.B.S. \\
\hline 5. & F. drymeja & W.P.B.S. \\
\hline 6. & F. mairei St. Yves Bs 3065 & W.P.B.S. \\
\hline 7. & F. pratensis Huds. cv. S215 & W.P.B.S. \\
\hline 8. & F. pratensis Huds. Induced & \\
\hline 9. & $\begin{array}{l}\text { autotetraploid cv. } S 215 \\
F \text {. arundinacea var. glaucescens }\end{array}$ & W.P.B.S. \\
\hline & Boiss. Bn 354 & W.P.B.S. \\
\hline 10. & F. arundinacea $\mathrm{cv} . \mathrm{S} 170$ & W.P.B.S. \\
\hline 11. & $\begin{array}{l}\text { F. arundinacea var. atlantigena } \\
\text { forma pseudo-mairei } \mathrm{Bl} 867\end{array}$ & W.P.B.S. \\
\hline 12. & F. arundinacea var. letourneauxiana & W.P.B.S. \\
\hline 13. & F. rubra subsp. rubra & W.P.B.S. \\
\hline 14. & F. alpina Suter. & $\begin{array}{l}\text { Botanischer Garten der Stadt Essen, W. } \\
\text { Germany }\end{array}$ \\
\hline $\begin{array}{l}15 . \\
16 .\end{array}$ & $\begin{array}{l}\text { F. rupicaprina (Hack.) Kern. } \\
\text { F. ovina var. firmula }\end{array}$ & $\begin{array}{l}\text { Université Strasbourg, France } \\
\text { Jardin Botanique de la ville, Dijon, } \\
\text { France }\end{array}$ \\
\hline 17. & F. arundinacea Schreb. & $\begin{array}{l}\text { Jardin Botanique de la ville, Besançon, } \\
\text { France }\end{array}$ \\
\hline 18. & F. gigantea C.L./Vill. & $\begin{array}{l}\text { Zentralinstitut für Genetik und } \\
\text { Kulturpflanzenforchung, Gatersleben, } \\
\text { DDR }\end{array}$ \\
\hline 19. & F. pratensis Huds. & Agricultural University of Norway \\
\hline
\end{tabular}

* W.P.B.S. $=$ Welsh Plant Breeding Station, Aberystwyth, U.K.

\section{RESULTS AND DISCUSSION}

(i) The extent of DNA variation in Festuca

The mean 2C nuclear DNA contents of the 19 taxa (table 2) ranged from $2.88 \mathrm{pg}$ in $F$. alpina to $13.40 \mathrm{pg}$ in $F$. arundinacea var. letourneauxiana-a difference of more than 4-fold. Only some of this variation could be accounted for by differences in chromosome number which ranged from $2 n=14$ to $2 n=70$. Thus among diploids, the species with the highest DNA content $(F$. drymeja) had about two and a half times more DNA than that with the lowest ( $F$. alpina). There was about a 1.4 fold variation in DNA content between the hexaploid taxa. Measurements of nuclear area 
TABLE 2

Mean 2C nuclear DNA contents (with standard errors in brackets) and chromosome numbers of 19 Festuca taxa

\begin{tabular}{|c|c|c|c|}
\hline Taxon & $\begin{array}{l}\text { DNA content } \\
(\mathrm{pg})\end{array}$ & $\begin{array}{c}\text { No. of } \\
\text { plants scored }\end{array}$ & $\begin{array}{l}\text { Chromosome } \\
\text { number }(2 n)\end{array}$ \\
\hline 1. F. alpina & $2.88(0.07)$ & 2 & 14 \\
\hline 2. F. rupicaprina & $2.96(0.07)$ & 6 & 14 \\
\hline 3. F. polesica & $3.40(0.05)$ & 9 & 14 \\
\hline $\begin{array}{l}\text { 4. F. pratensis } \\
\text { (Norwegian popul.) }\end{array}$ & $3.78(0 \cdot 12)$ & 3 & 14 \\
\hline 5. $F$. pratensis cv. $\mathrm{S} 215$ & $3.96(0.06)$ & 18 & 14 \\
\hline 6. F. scariosa & $4.73(0.09)$ & 9 & 14 \\
\hline 7. F. altissima & $5.79(0.15)$ & 5 & 14 \\
\hline 8. F. donax & $6 \cdot 36(0 \cdot 14)$ & 6 & 14 \\
\hline 9. F. drymeja & $7 \cdot 17(1 \cdot 10)$ & 6 & 14 \\
\hline 10. F. mairei & $6.93(0 \cdot 10)$ & 6 & 28 \\
\hline $\begin{array}{l}\text { 11. F. arundinacea var. } \\
\text { glaucescens }\end{array}$ & $7.62(0.04)$ & 6 & 28 \\
\hline $\begin{array}{l}\text { 12. F. pratensis } \\
\text { (autotetraploid S215) }\end{array}$ & $7.94(0.19)$ & 6 & 28 \\
\hline 13. F. rubra subsp. rubra & $8 \cdot 37(0 \cdot 06)$ & 3 & 42 \\
\hline 14. F. ovina var. firmula & $9 \cdot 23(0.18)$ & 2 & 42 \\
\hline $\begin{array}{l}\text { 15. F. arundinacea } \\
\text { (nat. popul.) }\end{array}$ & $10.53(0.43)$ & 3 & 42 \\
\hline 16. $F$. arundinacea $\mathrm{cv} . \mathrm{S} 170$ & $11.66(0 \cdot 20)$ & 6 & 42 \\
\hline $\begin{array}{l}\text { 17. F. arundinacea var. } \\
\text { atlantigena forma pseudo-mairei }\end{array}$ & $11 \cdot 19(0 \cdot 14)$ & 6 & 56 \\
\hline 18. F. gigantea & $12 \cdot 82(0 \cdot 19)$ & 3 & 56 \\
\hline $\begin{array}{l}\text { 19. F. arundinacea var. } \\
\text { letourneauxiana }\end{array}$ & $13 \cdot 40(0 \cdot 29)$ & 6 & 70 \\
\hline
\end{tabular}

showed that, in general, increases in nuclear DNA content were accompanied by increases in nuclear size.

Fig. 1 shows that nuclear DNA contents of diploids in Festuca are low when compared with those of diploid species from other genera of the Poaceae for which measurements for more than one species are available. The variation among species is similar to that in most other genera. DNA contents of polyploids in Festuca are also low compared with those of other genera in the Poaceae.

Variation within and between taxa of the same species and ploidy was generally insignificant. For example, two diploid samples of $F$. pratensis (the cultivar S215 and a natural population from Norway) showed no significant difference in DNA content. However, at the hexaploid level, a significant difference in DNA content was found between a cultivar and a natural population of $F$. arundinacea. Intraspecific variation in somatic chromosome morphology has also been found in hexaploid $F$. arundinacea (Malik and Thomas, 1966), including differences in chromosome size between populations which may suggest DNA variation.

\section{(ii) The pattern of DNA variation}

The nuclear DNA contents in table 2 show continuous variation throughout the range. There were no obvious gaps or clusters of taxa in 


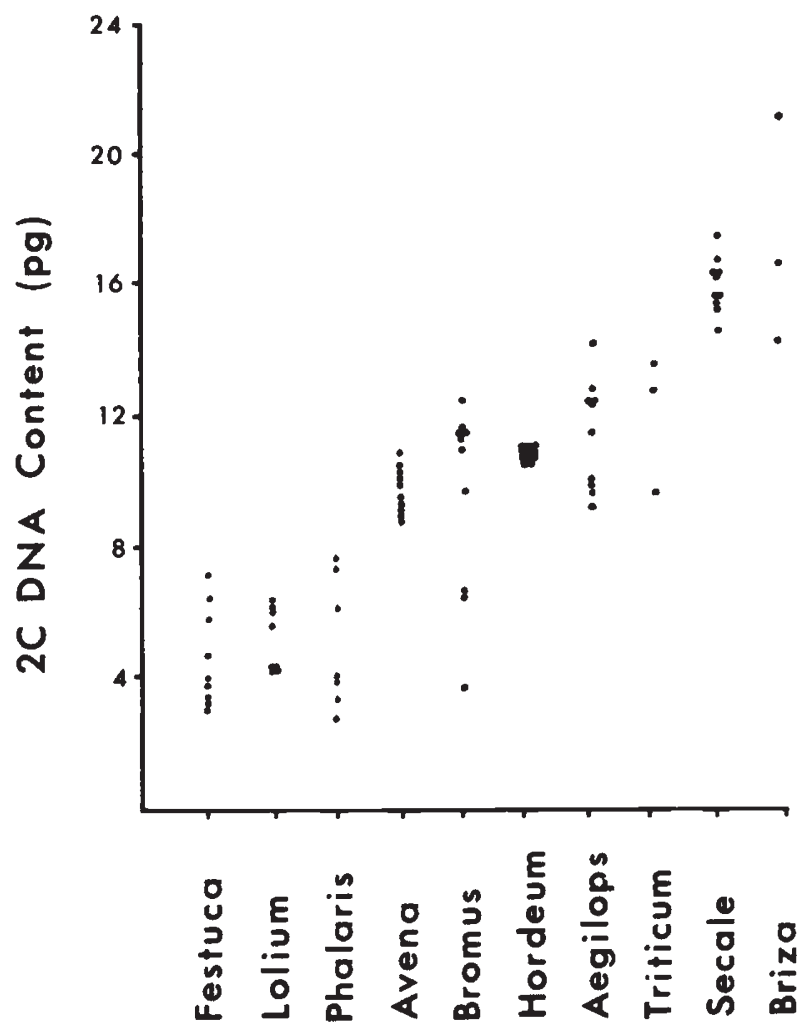

\section{Genus}

FIG. 1. Nuclear DNA contents of diploid species in the Poaceae. Data taken from Bennett and Smith, 1976 except for Festuca (data from present work) and Lolium (data from Hutchinson et al., 1979).

any particular part of the range. This is remarkable in that taxa from five different ploidy levels are included. For example, the diploid $F$. drymeja has at least as much DNA as $F$. mairei which has twice as many chromosomes. Thus, a similar DNA content may be achieved in different species via very different evolutionary pathways. Another example of this phenomenon was previously found in the genus Allium (Jones and Rees, 1968).

The genus Festuca has been divided into sections on the basis of leaf morphology and the structure of the ovary (Hackel, 1882). Four of the six recognised sections were represented in this survey. The classification of the taxa into their respective sections shows a remarkable correspondence with their DNA contents (fig. 2). Within the diploids for example, the three taxa from the Montanae section have the highest mean DNA contents. The single diploid of the section Scariosae lies between the Montanae and Bovinae taxa while the three Ovinae taxa have the lowest DNA contents. Among the tetraploids, the Bovinae taxa each have more DNA than F. mairei-a tetraploid species of the Scariosae section. At the hexaploid level the two Ovinae fescues (as in the case of the diploids) have lower 


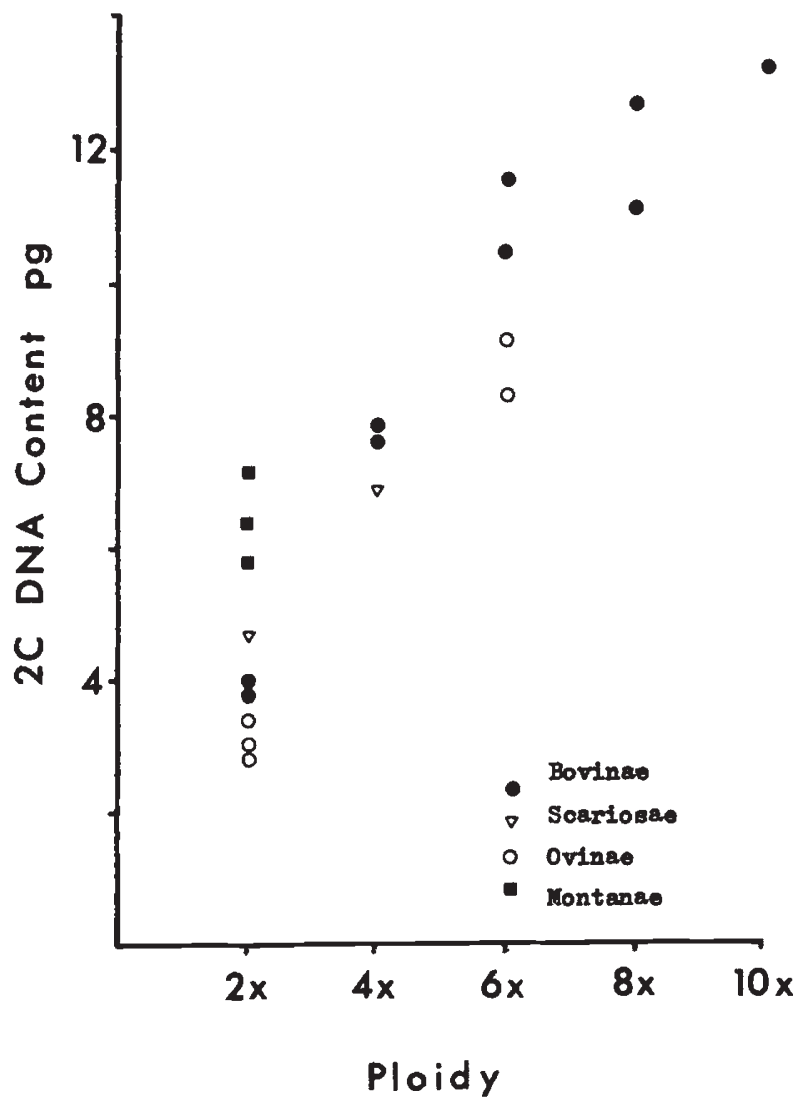

FIG. 2. The relationship between nuclear DNA content, ploidy and taxonomic divisions for the Festuca taxa listed in tables 1 and 2.

DNA contents than the two arundinacea taxa of the Bovinae section. The higher polyploids tested here have all been placed in the section Bovinae. Thus, within each ploidy level there are no overlaps in terms of DNA content between taxa of the different taxonomic sections and therefore, the taxonomic divisions are reinforced by the present data.

(iii) Tracing the ancestry of polyploids

Nuclear DNA contents have sometimes been used as evidence in proposing the possible origin of polyploid species (Rees and Walters, 1965). For example, if the sum of the DNA contents of two putative diploid ancestors matches the DNA content of the derived tetraploid then it is taken as evidence in favour of the origin of the tetraploid by doubling of the ancestral diploid hybrid. Rees and Walters (1965) using this approach, concluded that Aegilops speltoides was the most likely donor of the B genome in tetraploid wheat.

Malik and Thomas (1966) made the first detailed comparison of somatic chromosome morphology in Festuca species, all of which are outbreeders. 
They concluded that most polyploids were allopolyploids, none originating as a result of true autopolyploidy alone. Within the section Bovinae, similarities were found between the karyotypes of $F$. pratensis (diploid) and the tetraploid, hexaploid and decaploid varieties of $F$. arundinacea. A link was also indicated between the karyotypes of $F$. arundinacea var. glaucescens and F. mairei of the sections Bovinae and Scariosae respectively.

Malik and Thomas (1967) found that despite karyotypic diversity many species formed viable hybrids. The meiotic behaviour of several intra- and interspecific hybrids was described and genomic formulae proposed. The results of subsequent studies are summarised in table 3 . The genomic formulae were compiled from those of Chandrasekharan and Thomas (1971b) and Bowman and Thomas (1976).

\section{F. arundinacea $(6 \mathrm{x})$}

Chandrasekharan and Thomas (1971a) proposed, on the basis of morphological data, that $F$. arundinacea var. glaucescens $(4 \mathrm{x})$ and $F$. pratensis (2x) were the progenitors of the hexaploid $F$. arundinacea. The sum of the DNA contents of the proposed ancestral species $(11.58 \mathrm{pg})$ is very close to the DNA content of the hexaploid $F$. arundinacea $\mathrm{cv}$. S170 $(11.66 \mathrm{pg})$. Despite some intraspecific variation in DNA content among hexaploid varieties clearly hexaploid $F$. arundinacea could have arisen by chromosome doubling of the $\mathrm{F}_{1}$ hybrid between $F$. arundinacea var. glaucescens and $F$. pratensis, without invoking subsequent changes in DNA content. However, the $2 n=42$ colchiploid of the $F$. arundinacea var. glaucescens $\times$ $F$. pratensis $\mathrm{F}_{1}$ hybrid is morphologically unlike $6 \times$ F arundinacea (Borrill, pers. comm.).

\section{F. mairei $(4 \mathrm{x})$}

Malik and Thomas (1966) suggested, on the basis of similarity between some mitotic satellited chromosomes, that $F$. mairei $(4 \mathbf{x})$ and $F$. arundinacea var. glaucescens $(4 \mathrm{x})$ share one common genome. Meiosis in the tetraploid hybrid is characterised by a large number of bivalent associations (Malik and Thomas, 1967). This was confirmed by Bowman and Thomas (1976) who also found an appreciable frequency of quadrivalents in the colchicine derived $8 \mathrm{x}$ amphiploid. There is strong evidence that $F$. arundinacea var. glaucescens contains at least one genome from $F$. pratensis (Malik and Thomas, 1967) which is absent from $F$. mairei. Since the DNA contents of $F$. arundinacea var. glaucescens and $F$. pratensis are known, the DNA content of the genome common to both tetraploids would be, by subtraction, $3.66 \mathrm{pg}$. The remaining genome in $F$. mairei would then have a disomic DNA content of only $3.27 \mathrm{pg}$ compared with $4.73 \mathrm{pg}$ of $F$. scariosa, the proposed diploid donor species (Borrill, 1972).

\section{F. arundinacea var. atlantigena forma pseudo-mairei $(8 \mathrm{x})$}

$F$. arundinacea var. atlantigena forma pseudo-mairei $(8 \mathrm{x})$ was thought to combine the genomes of $F$. arundinacea var. glaucescens and $F$. maire $i$ (Chandrasekharan and Thomas, 1971b). Assuming no subsequent genomic 
DNA changes, the expected DNA content of an octoploid derived in this way would be $14.55 \mathrm{pg}$ which is 26 per cent more than the observed value (table 3).

TABLE 3

Comparison of observed DNA contents (Obs.) of Festuca taxa and those expected (Exp.) on the basis of proposed genomic formulae

\begin{tabular}{|c|c|c|c|c|}
\hline \multirow[b]{2}{*}{ Taxa } & \multirow[b]{2}{*}{ Ploidy } & \multirow{2}{*}{$\begin{array}{l}\text { Proposed genomic } \\
\text { formulae }\end{array}$} & \multicolumn{2}{|c|}{$\begin{array}{l}2 \mathrm{C} \text { nuclear DNA } \\
\text { contents }(\mathrm{pg})\end{array}$} \\
\hline & & & Obs. & Exp. \\
\hline \multirow{6}{*}{$\begin{array}{l}\text { F. pratensis } \\
\text { F. arundinacea var. } \\
\text { glaucescens } \\
\text { F. mairei } \\
\text { F. arundinacea } \\
\text { F. arundinacea var. } \\
\text { atlantigena forma } \\
\text { pseudo-mairei } \\
\text { F. arundinacea var. } \\
\text { letourneauxiana }\end{array}$} & $2 x$ & PP & 3.96 & \\
\hline & $4 x$ & AAGG & $7 \cdot 62$ & \\
\hline & $4 x$ & AAMM & 6.93 & \\
\hline & $6 x$ & PP AAGG & $10.53 / 11.66$ & $11 \cdot 58$ \\
\hline & $8 x$ & AAGG AAMM & $11 \cdot 59$ & $14 \cdot 55$ \\
\hline & $10 \mathrm{x}$ & PP AAGG AAMM & $13 \cdot 40$ & $17 \cdot 46 / 18 \cdot 5$ \\
\hline
\end{tabular}

\section{F. arundinacea var. letourneauxiana $(10 \mathrm{x})$}

The decaploid form was thought to combine the genomes of $F$. arundinacea $(6 \mathrm{x})$ and $F$. mairei, $4 \mathrm{x}$ (Borrill, 1972). Combining $F$. mairei with the arundinacea hexaploid taxon in table 1 having the lowest DNA content would produce a decaploid with 30 per cent more than the observed nuclear DNA content of $F$. arundinacea var. letourneauxiana. Even the smallest diploid genome among the taxa listed in table 2 has more than one fifth of the DNA content of the decaploid. $F$. pratensis, the only known diploid in the section Bovinae (to which the decaploid is assigned), has a DNA content of about one third of the corresponding decaploid value (table 2). Indeed, the highest possible DNA content of the smallest disomic genome in the decaploid is only $2.68 \mathrm{pg}(13.40$ divided by 5$)$.

Thus, the DNA contents of polyploid species, especially high polyploids ( $8 x$ and $10 x)$, are in most cases substantially less than expected on the basis of their proposed modes of origin. There are at least three possible explanations:

1. The DNA contents of polyploid species may, for technical reasons, have been underestimated.

In some surveys a disproportionate change in DNA content with increasing chromosome number has been shown to result from technical bias (Verma and Rees, 1974). Fig. 3 shows that as DNA content increases so too does the DNA density (DNA per unit area) of the nuclei. In some studies nuclear DNA estimates have been "corrected" to account for differences in DNA density which otherwise would have led to the underestimation of the DNA content of nuclei having a high DNA density (Verma and Rees, 1974). Such corrections were not applicable to the present results for three reasons. Firstly, squashing nuclei in acetic acid rather than glycerol produces higher estimates of DNA content and reduces the DNA density 


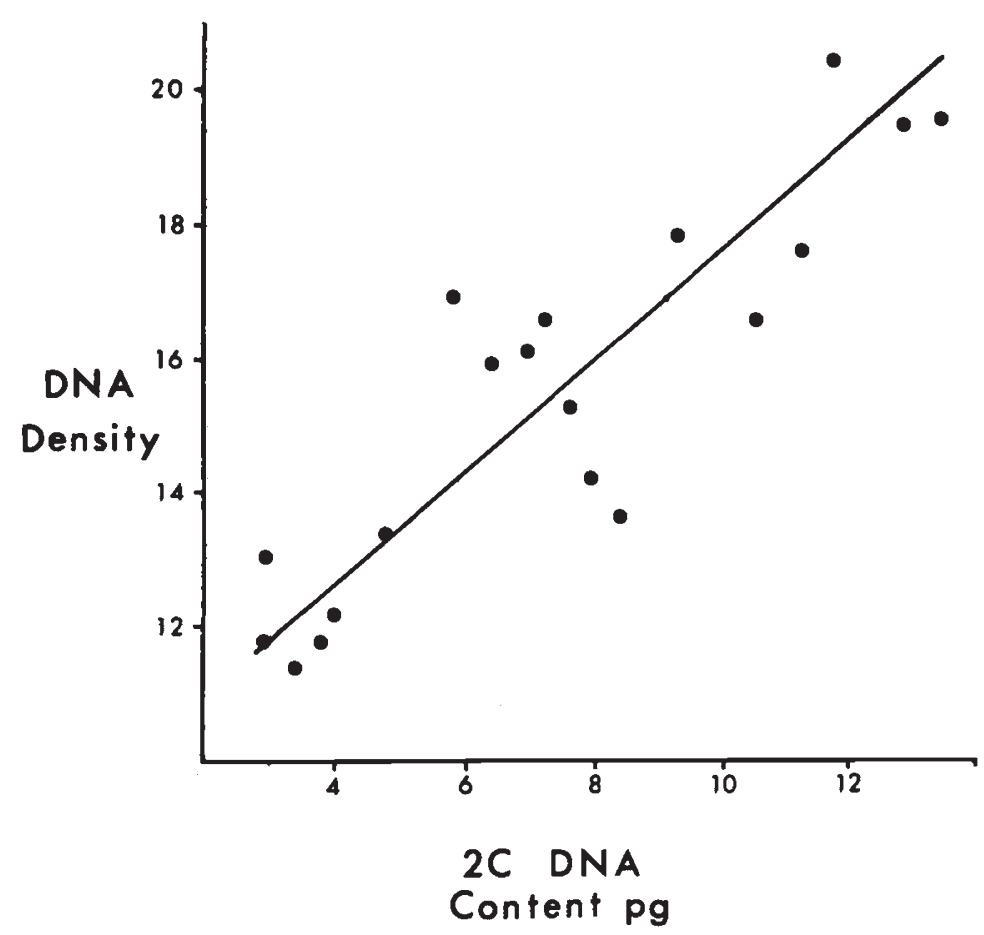

FIG. 3. The relationship between nuclear DNA density (DNA per unit area), expressed in arbitrary units, and nuclear DNA content of Festuca taxa.

of large nuclei (Seal-in preparation). Secondly, there was no significant correlation between DNA content and area (and, therefore, DNA density) for large nuclei squashed in acetic acid within individual slides. Only in the event of such a correlation is there any need for a "correction factor" (Verma and Rees, 1974). Thirdly, the inclusion of an induced tetraploid of $F$. pratensis cv. $\mathrm{S} 215$ in the present survey provided a direct test of the comparability of estimates of nuclear DNA content of two taxa differing in DNA content by a known factor (two-fold). A Chi-squared test showed no significant difference between the expected DNA content (calculated by doubling the diploid value) and the observed DNA content of the tetraploid despite a 17 per cent difference in DNA density.

From the above considerations it was assumed that all estimates in the present survey were comparable in their present form, with one possible reservation. The distribution of chromatin in nuclei of human fibroblast cells affects estimates of their DNA content made by Feulgen microdensitometry (Mittwoch, 1969). The DNA content of nuclei with dense chromocentres was underestimated when compared with similar nuclei showing a more uniform distribution of chromatin. In the present work it was noticed that the nuclei of Festuca species belonging to the section Ovinae consistently showed numerous dense chromocentres which were absent from the nuclei of other species. It is therefore possible that the nuclear DNA contents of species from this section were underestimated. However, since the estimated DNA contents of prophase nuclei which lack 
such chromocentres were close to the expected $4 \mathrm{C}$ value in the Ovinae species, large discrepancies of this nature are unlikely.

2. The proposed genomic formulae may be incorrect. The true diploid ancestral species may not be represented in the survey. They may be undiscovered or extinct.

Borrill (1972) divided the taxa of the Bovinae and Scariosae sections into two groups on the basis of geographical distribution, morphology and crossability. The first group, found in Morocco, includes $F$. mairei (4x), $F$. arundincea var. atlantigena forma pseudomairei $(8 \mathrm{x})$ and $F$. arundinacea varieties letourneauxiana and cirtensis $(10 \mathrm{x})$. The second group is predominantly European and includes $F$. pratensis $(2 \mathrm{x}), F$. arundinacea var. glaucescens $(4 \mathrm{x})$ and the hexaploid varieties of $F$. arundinacea. The results of Chandrasekharan et al., (1972) support the view that the Moroccan fescues are more closely related among themselves than to fescues from other regions. This contradicts the traditional classification of the three Moroccan types in which $F$. arundinacea var. atlantigena forma pseudomaire $i$ and $F$. arundinacea var. letourneauxiana are placed in the Bovinae section while $F$. mairei is in the Scariosae section. Indeed, Borrill (1972) suggested that these species should either all be included in an enlarged Scariosae section or that this section should be merged with the Bovinae.

The DNA contents of the Festuca taxa (tables 2 and 4) provide further evidence in support of the distinctive nature of the Moroccan group. The

TABLE 4

A comparison of the $2 C$ nuclear DNA contents of Festuca taxa from Morocco and Europe

\begin{tabular}{|c|c|c|c|c|}
\hline \multirow[b]{2}{*}{ Ploidy } & \multicolumn{4}{|c|}{ Nuclear DNA contents (pg) } \\
\hline & Moroccan taxa & & European taxa & \\
\hline $2 x$ & & & F.pratensis & 3.96 \\
\hline $4 x$ & F. mairei & 6.93 & $\begin{array}{l}F \text { arundinacea var. } \\
\text { glaucescens }\end{array}$ & $7 \cdot 62$ \\
\hline $6 x$ & & & F. arundinacea cv. $\$ 170$ & $11 \cdot 66$ \\
\hline $8 x$ & $\begin{array}{l}\text { F. arundinacea var. } \\
\text { atlantigena forma pseudo- } \\
\text { mairei }\end{array}$ & $11 \cdot 19$ & & \\
\hline $10 \mathrm{x}$ & $\begin{array}{l}\text { F. arundinacea var. } \\
\text { letourneauxiana }\end{array}$ & 13.40 & & \\
\hline
\end{tabular}

three Moroccan taxa are rather low in DNA content compared with European taxa. The tetraploid $F$. maire $i$ has the lowest DNA content among the tetraploid taxa. the octoploid, $F$. arundinacea var. atlantigena forma pseudo-mairei has a DNA content which is not significantly different from that of the hexaploid $F$. arundinacea cv. S170. The DNA content of the decaploid is too low to have been formed by multiplication of even the smallest diploid genome in the survey. The three Moroccan species show the greatest deviations of observed from expected DNA contents on the basis of their proposed genomic formulae. If these deviations are to be explained by the existence of unknown diploid species of low DNA content then perhaps it is Moroccan diploids that are missing. 
Table 2 shows that each step in the series $F$. scariosa $(2 \mathrm{x})-F$. mairei $(4 \mathbf{x})-F$. arundinacea var. atlantigena forma pseudo-mairei $(8 \mathbf{x})-F$. arundinacea var. letourneauxiana $(10 \mathrm{x})$ involves the addition of about $1.1 \mathrm{pg}$ of DNA per genome added. Whether this is coincidental or reflects the existence of optimal levels of DNA content or the addition of copies of a single genome is unknown. However, if such a genome did exist then the ancestral Moroccan diploid would have an expected DNA content of only $2 \cdot 2 \mathrm{pg}$. No Festuca species has yet been found with such a low DNA content and the existence of such a genome would undermine the close affinities found between European and Moroccan species by Chandrasekharan and Thomas (1971 $a$ and 1971b).

Borrill (1972), on morphological grounds, suggested that the three Moroccan polyploids had each incorporated at least one genome from the diploid $F$. scariosa. This diploid is now found only in the Sierra Nevada region of Spain but opportunities for hybridisation are thought to have once existed (Borrill, 1972). Such a relationship is not supported, however, by the cytogenetic evidence from triploid $F$. scariosa $(2 \mathrm{x}) \times F$. mairei $(4 \mathrm{x})$ or tetraploid $F$. scariosa $(4 \mathrm{x}) \times F$. mairei $(4 \mathrm{x})$ hybrids in which few meiotic associations were found between chromosomes of the two species (Bowman and Thomas, 1976). Unlike the Moroccan fescues, $F$. scariosa has a DNA content somewhat intermediate among other taxa of the same chromosome number (table 2). It seems unlikely that such a large genome could have combined with others to form the Moroccan polyploids without subsequent changes in DNA content.

Thus, the separation of the Moroccan from the European taxa provides a possible explanation of some of the discrepancies between the DNA contents and the accepted evolutionary pathways. Interestingly, the two groups comply with the cline of increasing DNA content with increasing latitude known to exist among many crop species (Bennett, 1976).

3. The DNA contents of the ancestral species may have changed relative to those of their derived polyploids since their divergence-the diploids having gained DNA or the polyploids having lost it. Two of the three Moroccan fescues are representatives of the highest polyploids in the genus. Perhaps their high chromosome numbers rather than their geographical distribution are related to the discrepancy between observed and expected DNA amounts. Such a relationship could be tested by matching the DNA contents of high polyploids from Europe with their proposed genomic constitutions when these become available. If these polyploids also show unexpectedly low DNA contents then one would conclude that upward changes in ploidy level may be accompanied or followed by loss of DNA. DNA diminution in polyploids has been proposed before (Pai et al., 1961; Yamaguchi and Tsunoda, 1969) but seldom confirmed (Rees and Walters, 1965; Verma and Rees, 1974). Alternatively, it is conceivable that the ancestral diploid genomes have differentially increased in DNA content since the formation of the polyploids.

If the "homoeologous" genomes of species of different ploidy levels differed in DNA content (and therefore size) one might expect to find heteromorphic bivalents in their $\mathrm{F}_{1}$ hybrids at meiosis. Malik and Thomas (1967) noted the occurrence of such bivalents in hybrids of $F$. pratensis $(2 \mathrm{x}) \times F$. glaucescens $(4 \mathrm{x}), F$. glaucescens $\times F$. arundinacea $(6 \mathrm{x})$, and $F$. arundinacea $(6 \mathrm{x}) \times$ the decaploid. Heteromorphic bivalents could, of 
course, arise without an accompanying change in genomic DNA content by translocation or by intragenomic pairing-a common feature in such hybrids (Malik and Thomas, 1967). However, changes in DNA content among polyploid species seem possible-even probable-when one considers the variation found among diploids. Changes in DNA amount between diploid species are undeniable. Moreover, they are of common occurrence and often of substantial size. $F$. drymeja and $F$. scariosa, for example, differ in nuclear DNA content by about 50 per cent and yet are sufficiently closely related to produce viable $F_{1}$ hybrids (Borrill et al., 1977). Thus, massive differences in genomic DNA content do not necessarily indicate extensive evolutionary divergence of two species. Moreover, since large-scale DNA variation is often found between closely related species the changes can, in evolutionary terms, occur rapidly. There is no reason why the genomes of polyploids should be immune from such changes. Indeed in view of the inevitable duplication of many DNA sequences in polyploids, they may be more tolerant of and, therefore, more prone to variation in DNA content than diploids (Jackson and Casey, 1980).

It seems then that the DNA content of a genome is not immutable and so its value in tracing the ancestry of polyploids is somewhat diminished. However, the correspondence of taxonomic divisions with the distribution of nuclear DNA contents in fig. 2 shows that the extent of divergence in DNA content may be a useful indication of the extent of evolutionary divergence among diploid species.

Acknowledgements. Thanks are due to Professor H. Rees, Dr M. Borrill, and Dr H. Thomas for their helpful comments and advice. This work was funded by an SRC studentship.

\section{REFERENCES}

BENNETT, M. D. 1976. DNA amount, latitude, and crop plant distribution. Environ. and Exp. Bot., 16, 93-108.

BORRILl, M. 1972. Studies in Festuca. III. The contribution of $F$. scariosa to the evolution of polyploids in sections Bovinae and Scariosae. New Phytol., 71, 523-532.

BORRILL, M., KIRBY, M. AND MORGAN, w. G. 1977. Studies in Festuca 11. Interrelationships of some putative diploid ancestors of the polyploid broad-leaved fescues. New Phytol., $78,661-674$.

BOWMAN. J. G. AND THOMAS, H. 1976. Studies in Festuca. 8. Cytological relationships between $F$. glaucescens $(2 n=28), F$. mairei $(2 n=28)$ and $F$. scariosa $(2 n=14) . Z$. Pflanzenzüchtg., 76, 250-257.

CHANDRASEKHARAN. P. AND THOMAS, H. 1971a. Studies in Festuca. 5. Cytogenetic relationships between species of Bovinae and Scariosae. Z. Pflanzenzüchtg., 65, 345-354.

CHANDRASEKharan, P. AND THOMAS, H. 1971b. Studies in Festuca. 6. Chromosome relationships between Bovinae and Scariosae. Z. Pflanzenzüchtg., 66, 76-86.

CHANDRASEKHARAN, P., LEWIS. E. J. AND BORRILL, M. 1972. Studies in Festuca. II. Fertility relationships between species of sections Bovinae and Scariosae, and their affinities with Lolium. Genetica, 43, 375-386.

HACKEL, E. 1882. Monographia Festucarum europaearum. Fischer, Kassel and Berlin. Reprinted by Micro Methods Ltd and Johnson Reprint Corp. 1964, Wakefield and New York.

HUTCHINSON, J., REES, H. AND SEAL, A. G. 1979. An assay of the activity of supplementary DNA in Lolium. Heredity, 43, 411-421.

JACKSON, R. C. AND CASEY, J. 1980. Cytogenetics of polyploids. In Lewis, W. H. (ed.) Polyploidy: Biological Relevance, Plenum Press, New York and London, pp. 17-44.

JONES, R. N. 1975. B-chromosome systems in flowering plants and animal species. Int. Rev. Cytol., 40,1-100.

JONES, R. N. AND REES, H. 1968. Nuclear DNA variation in Allium. Heredity, 23, 591-605. 
MALIK, C. P. AND THOMAS, P. T. 1966. Karyotypic studies in some Lolium and Festuca species. Caryologia, 19, 167-196.

MALIK, C. P. AND THOMAS, P. T. 1967. Cytological relationships and genome structure of some Festuca species. Caryologia, 20, 1-39.

MITTWOCH, U. 1969. Scope and limitations of Feulgen microdensitometry. Chromosomes Today, 2, 90-98.

PAI, R. A., UPADHYA, M. D., BHASKAVAN, S. AND SWAMINATHAN, M. S. 1961. Chromosome diminution and evolution of polyploid species in Triticum. Chromosoma, 12, 398-409.

REES, H. AND JONES, G. H. 1967. Chromosome evolution in Lolium. Heredity, 22, 1-18.

REES, H. AND WALTERS, M. R. 1965. Nuclear DNA and the evolution of wheat. Heredity, $20,73-82$.

SEAL, A. G. AND REES, H. 1982. The distribution of quantitative DNA changes associated with the evolution of diploid Festuceae. Heredity, 49, 181-192.

VAN'T HOF, J. 1965. Relationships between mitotic cycle duration, $S$ period duration and the average rate of DNA synthesis in the root meristem cells of several plants. Expl. Cell Res., 39, 48-58.

VERMA, S. C. AND REES, H. 1974. Nuclear DNA and the evolution of allotetraploid Brassicae. Heredity, 33, 61-68.

YAMAGUCHI, Y. AND TSUNODA, S. 1969. Nuclear volume, nuclear DNA content and radiosenstivity in Brassica and allied genera. Japan J. P. Breeding, 19, 350-356. 